\title{
TGF $\beta R 2$ is a major target of miR-93 in nasopharyngeal carcinoma aggressiveness
}

Xiaoming Lyu ${ }^{1 \dagger}$, Weiyi Fang ${ }^{1 \dagger}$, Longmei Cai ${ }^{1 \dagger}$, Hang Zheng ${ }^{1,4 \dagger}$, Yanfen $\mathrm{Ye}^{1}$, Lan Zhang ${ }^{3}$, Jinbang $\mathrm{li}^{1}$, Hong Peng ${ }^{3}$, William C S Cho ${ }^{5}$, Ena Wang ${ }^{6}$, Francesco M Marincola ${ }^{6}$, Kaitai Yao ${ }^{1}$, Hongbing Cai ${ }^{2^{*}}$, Jiliang $\mathrm{Li}^{7,8^{*}}$ and Xin $\mathrm{Li}^{\mathrm{i}^{*}}$

\begin{abstract}
Background: MiR-17-92 cluster and its paralogues have emerged as crucial regulators of many oncogenes and tumor suppressors. Transforming growth factor- $\beta$ receptor II (TGF $\beta R 2)$, as an important tumor suppressor, is involved in various cancer types. However, it is in cancer that only two miRNAs of this cluster and its paralogues have been reported so far to regulate TGF $\beta$ R2. MiR-93 is oncogenic, but its targetome in cancer has not been fully defined. The role of miR-93 in nasopharyngeal carcinoma (NPC) still remains largely unknown.

Methods: We firstly evaluated the clinical signature of TGF $\beta R 2$ down-regulation in clinical samples, and next used a miRNA expression profiling analysis followed by multi-validations, including Luciferase reporter assay, to identify miRNAs targeting TGF $\beta R 2$ in NPC. In vitro and in vivo studies were performed to further investigate the effects of miRNA-mediated TGF 3 R2 down-regulation on NPC aggressiveness. Finally, mechanism studies were conducted to explore the associated pathway and genes influenced by this miRNA-mediated TGF $\beta R 2$ down-regulation.

Results: TGF $\beta R 2$ was down-regulated in more than $50 \%$ of NPC patients. It is an unfavorable prognosis factor contributing to clinical NPC aggressiveness. A cluster set of 4 TGF $\beta R 2$-associated miRNAs was identified; they are all from miR-17-92 cluster and its paralogues, of which miR-93 was one of the most significant miRNAs, directly targeting TGF $\beta$ R2, promoting cell proliferation, invasion and metastasis in vitro and in vivo. Moreover, miR-93 resulted in the attenuation of Smad-dependent TGF- $\beta$ signaling and the activation of PI3K/Akt pathway by suppressing TGF $\beta$ R2, further promoting NPC cell uncontrolled growth, invasion, metastasis and EMT-like process. Impressively, the knockdown of TGF $\beta R 2$ by siRNA displayed a consentaneous phenocopy with the effect of miR-93 in NPC cells, supporting TGF $\beta$ R2 is a major target of miR-93. Our findings were also substantiated by investigation of the clinical signatures of miR-93 and TGFBR2 in NPC.
\end{abstract}

Conclusion: The present study reports an involvement of miR-93-mediated TGF $\beta$ R2 down-regulation in NPC aggressiveness, thus giving extended insights into molecular mechanisms underlying cancer aggressiveness. Approaches aimed at blocking miR-93 may serve as a promising therapeutic strategy for treating NPC patients.

Keywords: miR-93, TGFßR2, Aggressiveness, PI3K/Akt, Nasopharyngeal carcinoma

\footnotetext{
*Correspondence: chbing2008@126.com; ji-liang.li@imm.ox.ac.uk; xinli268@gmail.com

${ }^{\dagger}$ Equal contributors

${ }^{2}$ School of Chinese Traditional Medicine, Southern Medical University, Guangzhou, China

${ }^{7}$ School of Biotechnology, Southern Medical University, Guangzhou, China

${ }^{1}$ Cancer Research Institute and the Provincial Key Laboratory of Functional

Proteomics, Southern Medical University, Guangzhou, China

Full list of author information is available at the end of the article
}

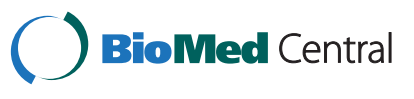

(c) 2014 Lyu et al.; licensee BioMed Central Ltd. This is an Open Access article distributed under the terms of the Creative Commons Attribution License (http://creativecommons.org/licenses/by/2.0), which permits unrestricted use, distribution, and reproduction in any medium, provided the original work is properly credited. The Creative Commons Public Domain Dedication waiver (http://creativecommons.org/publicdomain/zero/1.0/) applies to the data made available in this article, unless otherwise stated. 


\section{Introduction}

Transforming growth factor- $\beta$ (TGF- $\beta$ ) signaling has tumor suppressive and pro-oncogenic functions in accordance with tumor stage [1]. Its abrogation is always accomplished by either blockade of TGF- $\beta$ responses or the acquisition of genetic alterations and epigenetic modifications in its components including transforming growth factor- $\beta$ receptor II (TGF $\beta$ R2) [2]. TGF $\beta$ R2, as a tumorsuppressor gene $[3,4]$ is downregulated in multiple cancer types including head and neck squamous cell carcinoma (HNSCC) and is generally related to cancer aggressive behavior [5-9]. Cancer cells always lose their sensitivity to TGF- $\beta$-mediated growth inhibitory responses upon TGF $\beta R 2$ down-regulation [10]. The mechanisms underlying the downregulation of TGF $\beta R 2$ expression in cancer cells have been investigated, showing that repressed expression of TGF $\beta R 2$ in microsatellite instability-high colorectal cancer and esophageal adenocarcinoma involves hypermethylation of the TGF $\beta$ R2 promoter region $[11,12]$. However, TGF $\beta$ R2 promoter methylation is not frequent in some cancers such as Head and neck squamous cell carcinoma (HNSCC) (11.4\%) [13], although there is a frequent loss of TGF $\beta$ R2, suggesting that other mechanisms may contribute to the downregulation of TGF $\beta$ R2 expression.

MiRNAs have emerged as important regulators of gene expression. They can modulate multiple biological processes by inducing translational inhibition and/or mRNA degradation of protein-coding genes. The miR-17-92 cluster is among the best-studied miRNA clusters in carcinogenesis, also known as 'oncomiR-1' [14]. It has pivotal roles in a variety of cancers such as colorectal cancer [15-17], breast cancer [18-21], pancreatic cancer [22,23], ovarian cancer [24], lung cancer [25,26], and hepatocellular carcinoma [27-29]. MiR-93, derived from a paralogue (miR-106b25) of miR-17-92 cluster, is up-regulated in various types of cancers [30-32]. The identified targets of miR-93 include LATS2 [33], AICDA [34], ITGB8 [35], PTEN [36], VEGFA [37], TP53INP1 [38], DAB2 [39], etc., suggesting that miR93 may play oncogenic roles through diverse mechanisms. However, the targetome of miR-93 in cancer has not been fully defined so far. The role of miR-93 in nasopharyngeal carcinoma (NPC) still remains largely unknown.

We previously found a reduced TGF $\beta$ R2 expression in NPC [40], which was subsequently supported by the findings from Zhang et al. [41]. Although many miRNAs (For example miR-26a [42,43], miRNA-18a [44], miR18b [45], miR-218 [46], miR-216b [47], miR-663 [48], miR-155 [49], miR-205 [50], EBV-encoded miRNAs [51], etc.) have been reported to be involved in NPC carcinogenesis, no evidence was given for their associations with TGFßR2 down-regulation.

In the current study, using a miRNA expression profiling analysis in NPC samples stratified by TGF $\beta$ R2 expression level, we identified a cluster set of 4 TGF $\beta R 2-$ associated miRNAs (miR-93, miR-20a, miR-20b, and miR18a). They are all from miR-17-92 cluster and its paralogues, of which miR-93 was one of the most significant miRNAs. We demonstrated that miR-93 could directly suppress TGF $\beta 2$ and facilitate NPC aggressiveness (NPC cell growth, metastasis and EMT-like process). Mechanistic investigation disclosed that miR-93 could result in attenuated Smad-dependent TGF-B pathway and activated PI3K/Akt pathway by suppressing TGF $\beta$ R2.

Thus, our study first reports a miR-93-mediated TGF $\beta$ R2 down-regulation in NPC, extending novel mechanistic insights into the role of miR-93 in cancer aggressiveness. Blocking of miR-93 may be a promise for cancer therapy.

\section{Results}

\section{TGF $\beta$ R2 down-regulation is associated with NPC}

\section{aggressiveness}

Our previous study reported a down-regulated TGF $\beta$ R2 expression in NPC [40], so we initially confirmed it in the present study. TGF $\beta$ R2 expression was indeed observed to be significantly reduced in NPC patients relative to non-cancerous nasopharyngeal (NP) (Figure 1A). Next, we investigated the clinical signature of TGF $\beta R 2$ down- regulation using $\mathrm{IHC}$ in additional 300 clinical NPC samples. TGF $\beta 2$ protein was down-regulated in $51.9 \%(108 / 208)$ of NPC, $38.5 \%$ (5/13) of atypical hyperplasia, $9.1 \%(2 / 22)$ of normal squamous epithelium, and $5.3 \%(3 / 57)$ of normal epithelium, displaying a gradual reduction trend from normal epithelium to NPC (Table 1). Pathological analysis showed that the expression level of TGFßR2 is negatively correlated with $\mathrm{T}$ classification (the size of the primary tumor and whether it has invaded nearby tissue), $\mathrm{N}$ classification (the degree of spread to regional lymph nodes), and clinical stage of NPC patients (Additional file 1: Table S1). Kaplan-Meier survival analysis revealed that TGF $\beta$ R2 expression was significantly correlated with patient overall survival (Figure 1B, C and Additional file 2: Figure S1). Multivariate survival analysis using the Cox's proportional hazards model showed a close correlation of low TGF $\beta$ R2 protein expression with clinical prognosis (Additional file 1: Table S2).

Subsequently, we examined the TGF $\beta$ R2 expressions in 4 NPC cell lines (CNE1, CNE2, 5-8 F, 6-10B), pooled NPC tissues, and an immortalized primary nasopharyngeal epithelial cell line (NP69). The mRNA and protein expressions of TGF $\beta 22$ were generally down-expressed in NPC cells and NPC tissues relative to NP69. The more metastatic or aggressive NPC cells (such as CNE2 and 5-8 F) had relatively lower TGF $\beta 22$ expression than that of NPC cells (such as CNE1 and 6-10B) with less metastatic or aggressive potential (Additional file 2: Figure S2). 


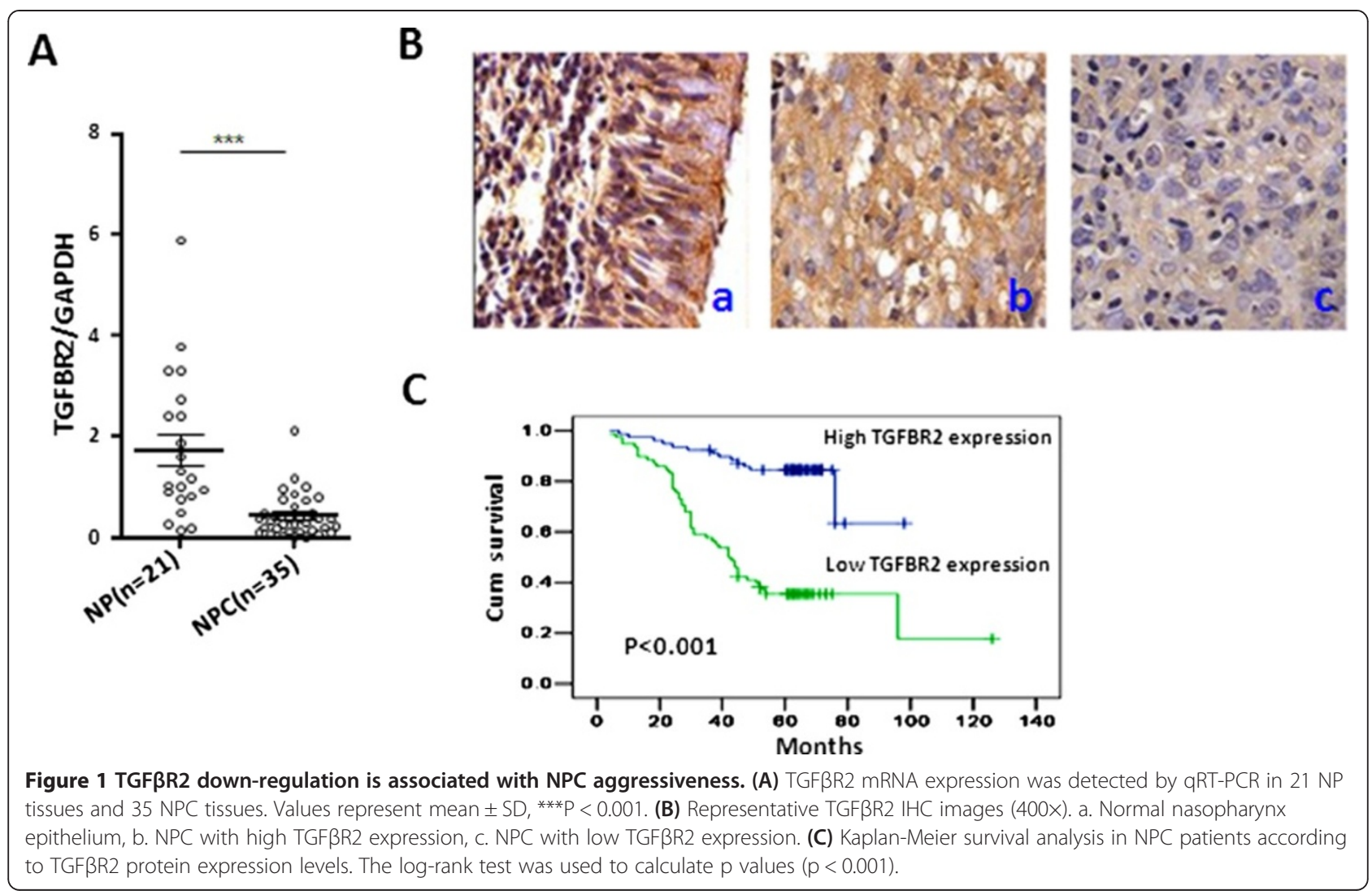

Collectively, these data support a close relevance of TGF $\beta R 2$ down-regulation to NPC aggressiveness.

\section{MiR-93 suppresses TGF $\beta$ R2 in NPC}

To investigate if miRNAs are involved in regulation of TGF $\beta 2$ expression in NPC, we first selected 22 clinical samples and stratified them into 3 groups based on the mRNA level of TGFßR2: (1) high expression NP group (H-NP) containing 8 NP samples, (2) high expression NPC group (H-NPC) containing 7 NPC samples, and (3) low expression NPC group (L-NPC) containing 7 NPC samples (Additional file 2: Figure S3). We then conducted a miRNA expression profiling analysis for these 3 groups. As shown in Figure 2A and Additional file 1: Table S3, significantly higher expressions of miR-93, miR-20a, miR- 20b, and miR-18a were observed in the L-NPC group. They are clustered together and all from miR-17-92 cluster and its paralogues. Of them, miR-93 gained our attention because it shows an oncogenic potential but it has been unclear whether miR-93 could regulate TGFBR2 in cancers, and no studies reported its roles and target genes in NPC. We applied qRT-PCR to confirm that miR-93 was highly expressed in NPC samples (Figure 2B) and 5 NPC cell lines (Additional file 2: Figure S4), and also observe that TGF $\beta$ R2 expression was inversely correlated with miR-93 expression $\left(R^{2}=0.3995\right)$ (Figure $2 C$, Additional file 2: Figure S3), suggesting that miR-93 may regulate TGF $\beta R 2$.

To determine whether TGF $\beta 2$ was a direct target of miR-93, we performed a bioinformatic analysis using RNAhybrid and TargetScan. It showed a complementary

Table 1 A gradual reduction trend of TGF $\beta R 2$ protein expression from normal epithelium to NPC

\begin{tabular}{|c|c|c|c|c|c|c|c|c|c|}
\hline \multirow[t]{2}{*}{ Group } & \multicolumn{3}{|c|}{ Protein expression $(\mathrm{n})$} & \multicolumn{6}{|c|}{$P$ value } \\
\hline & Total & Low & High & S/N/A/C & $\mathrm{S} / \mathrm{N}$ & $A / N$ & $\mathrm{C} / \mathrm{N}$ & $\mathrm{A} / \mathrm{C}$ & $\mathrm{S} / \mathrm{C}$ \\
\hline S & 22 & 2 & 20 & $<0.001^{*}$ & $0.614^{\#}$ & $0.005^{\#}$ & $<0.001^{\#}$ & $0.401^{\#}$ & $<0.001^{\#}$ \\
\hline $\mathrm{N}$ & 57 & 3 & 54 & & & & & & \\
\hline A & 13 & 5 & 8 & & & & & & \\
\hline C & 208 & 108 & 100 & & & & & & \\
\hline
\end{tabular}

S: Squamous epithelium; N: Normal epithelium; A: Atypical hyperplasia; C: NPC. n: Number of cases. ${ }^{*}$ Kruskal Wallis Test; ${ }^{*}$ Chi-square Test. 


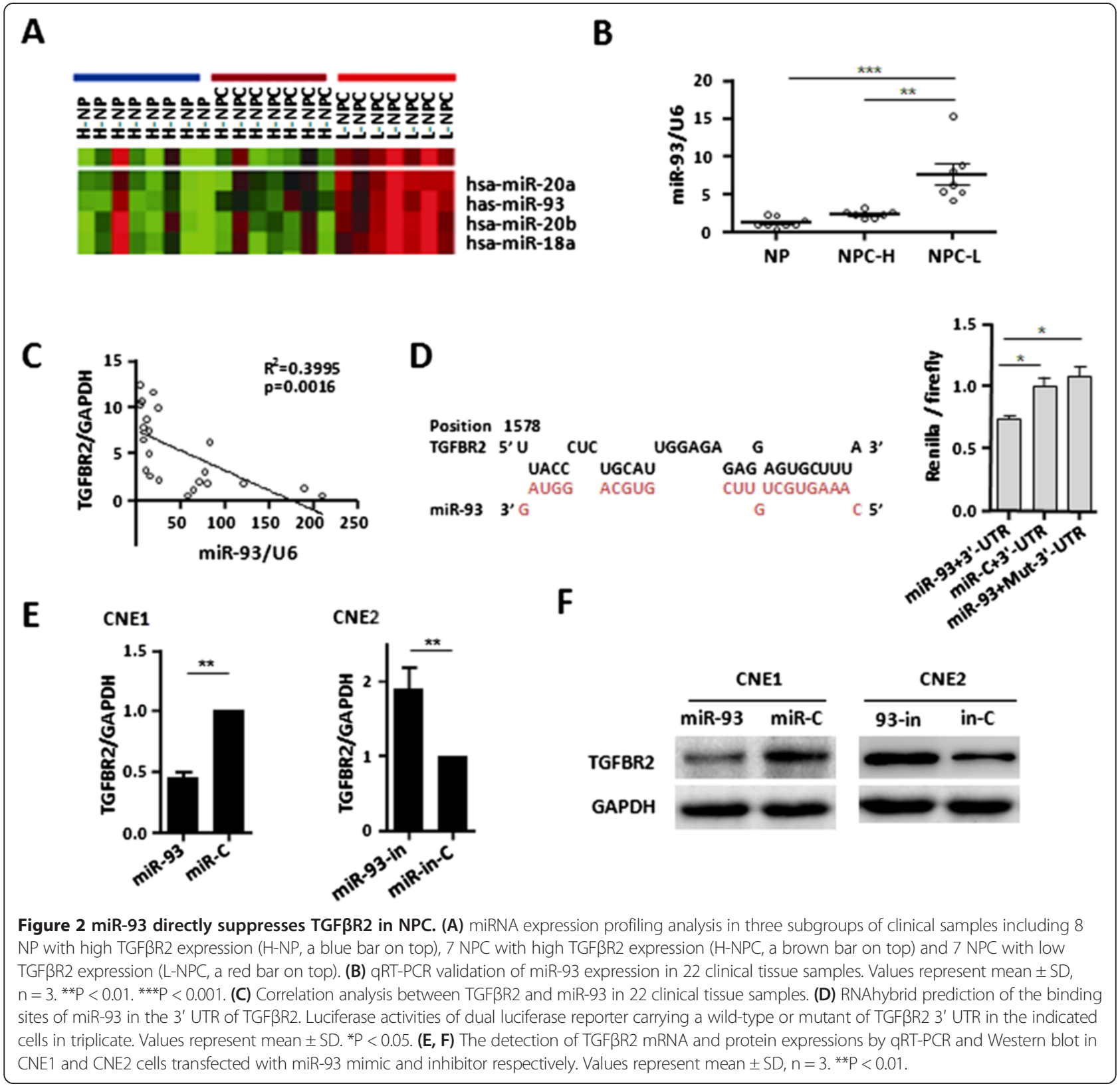

match between miR-93 seed sequence and the 3'UTR of TGFßR2 (Figure 2D, Additional file 2: Figure S5). Subsequent dual-luciferase reporter assays reveal that miR-93 significantly attenuated the luciferase activity of reporter vector with the wt 3'UTR of TGF $\beta R 2$, whereas this effect was abrogated when the 3'UTR-binding site was mutated, supporting that this miRNAs directly regulated TGF $\beta R 2$ by binding to its 3'UTR (Figure 2D).

According to the relatively high TGF $\beta$ R2 expression in CNE1 cells and low in CNE2 cells (Additional file 2: Figure S2) as well as relatively low miR-93 expression in CNE1 cells and high in CNE2 cells (Additional file 2: Figure S4), we transfected CNE1 and CNE2 cells with
miR-93 mimic and inhibitor, respectively. Both TGF $\beta$ 2 mRNA and protein expression levels were observed to decline in CNE1 cells and increase in CNE2 cells (Figure 2E, F) accordingly. These data further support that miR-93 directly suppresses TGF $\beta$ R2 in NPC.

MiR-93-mediated TGF $\beta$ R2 down-regulation enhances NPC aggressiveness

To explore the roles of miR-93-mediated TGF $\beta 22$ down-regulation in NPC aggressiveness, CNE1 and CNE2 cells were used in both gain- and loss-of-function analyses. 
We firstly investigated whether miR-93 was responsible for NPC cell growth and proliferation after regulating TGF $\beta$ R2 expression (Figure 2E, F). Colony formation assays showed that miR-93 mimic increased cell growth in CNE1 cells, whereas its inhibitor reduced cell growth in CNE2 cells (Figure 3A, B). Consistent results appeared in MTT assays (Additional file 2: Figure S6A, B). Flow cytometry analysis displayed that CNE1 cells transfected with miR-93 mimic exhibited a significantly reduced cell proportion in G1 phase and an increased cell proportion in S-phase. CNE2 cells transfected with miR93 inhibitor showed opposite alterations (Figure 3A, B, Additional file 2: Figure S7).

We next studied whether miR-93 was also involved in NPC cell invasion and migration after regulating TGF $\beta$ R2 expression (Figure 2E, F). Cell migration/invasion assays displayed that miR-93 mimic enhanced cell migration and invasion in CNE1 cells (Figure 3A, Additional file 2: Figure S8A), whereas miR-93 inhibitor restricted cell migration and invasion (Figure 3B, Additional file 2: Figure S8B) in CNE2 cells.
Impressively, further investigation showed that the knockdown of TGF $\beta 2$ by siRNA (Additional file 1: Table S4, Additional file 2: Figure S10A) enabled a reduced TGF $\beta R 2$ protein expression (Additional file 2: Figure S10B) along with enhanced proliferation and migration in CNE1 cells (Figure 3C). This phenocopied the effect of miR-93 and supported the major involvement of TGF $\beta R 2$.

To support in vitro results, we also conducted in vivo experiments. The CNE1 cell line stably-expressing miR-93 (CNE1-miR-93) was firstly generated using EGFP-LentimiR-93-vector (Additional file 2: Figure S11). Subsequently, we established xenograft mouse models subcutaneously injected with CNE1-miR-93 cells and miR-control cells. We observed that CNE1-miR-93 cells produced bigger tumor volumes in mouse models (Figure 4A). Immunohistochemistry (IHC) on tissue sections derived from tumors showed that TGF $\beta 22$ protein expression was reduced in the tumor induced by CNE1-miR-93 cells (Figure 4B). Additionally, we set up NPC metastasis mouse models by transplanting CNE1-miR-93 cells and

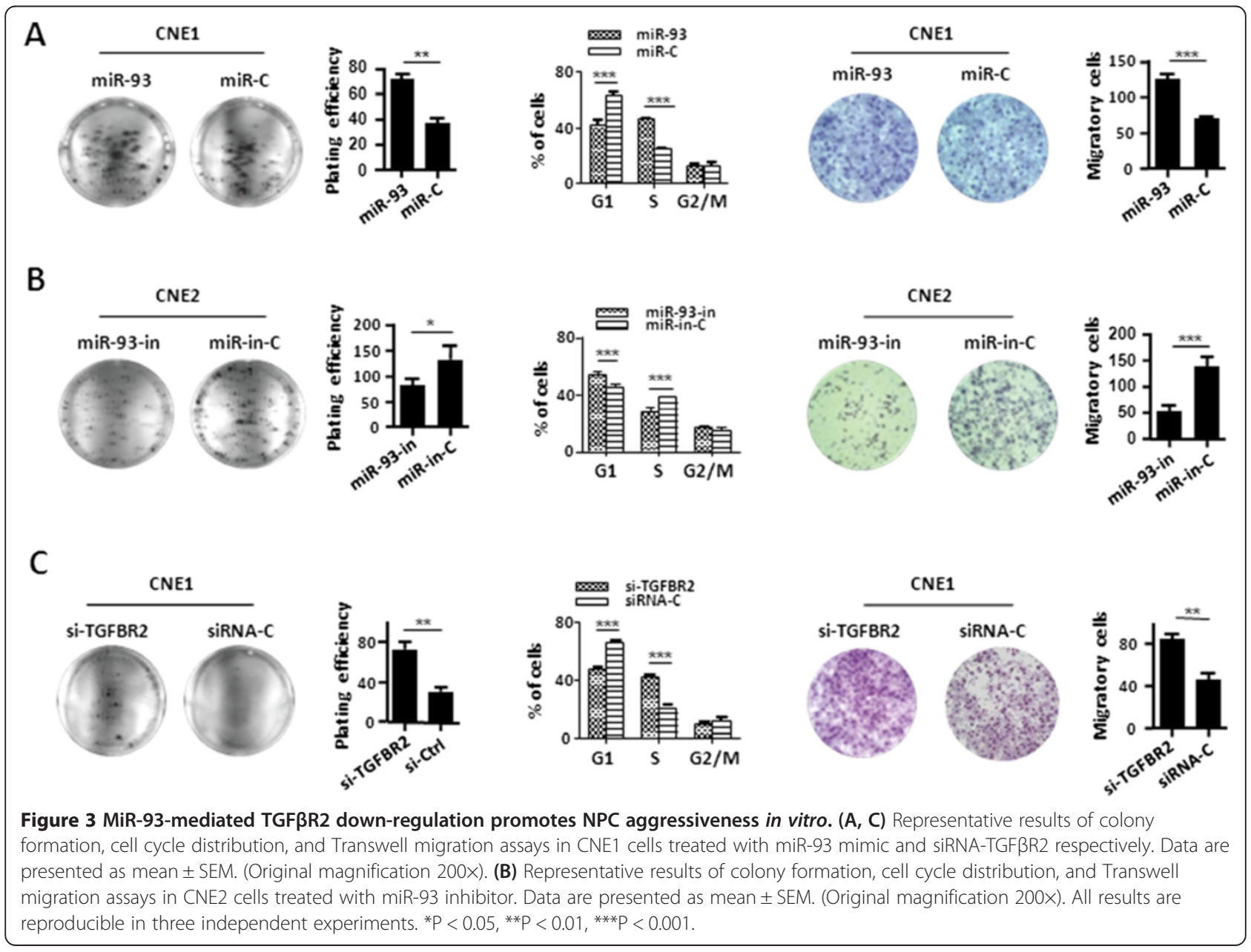




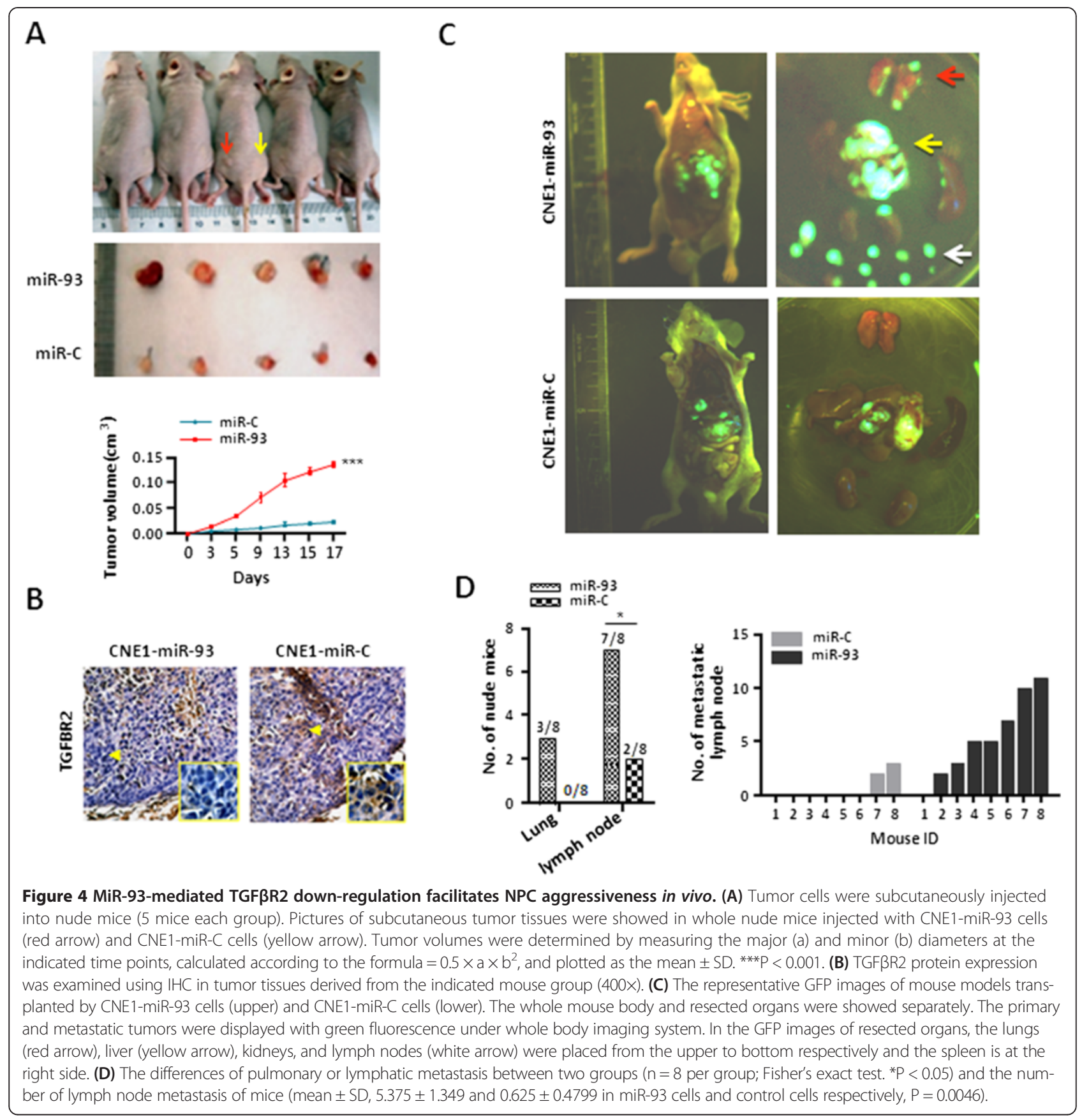

miR-control cells under liver capsule of mice respectively. The whole body fluorescent imaging system displayed a high metastasis status in a representative CNE1-miR-93 cell-injected mouse. The pulmonary or lymphatic metastasis incidence was obviously higher in CNE1-miR-93 cellinjected mice than in control mice (Figure 4C, D). Notably, miR-93 cells resulted in significantly more lymph node metastases $(5.375 \pm 1.349)$ than that of control cells in mouse models $(0.625 \pm 0.4799)(\mathrm{P}=0.0046)$ (Figure 4D).

Collectively, these in vitro and in vivo data suggest that miR-93-mediated TGF $\beta$ R2 down-regulation promote NPC aggressiveness through enhancing NPC cell proliferation, invasion and metastasis.

\section{MiR-93 regulates a Smad-dependent and a}

Smad-independent TGF- $\beta$ signaling by suppressing TGF $\beta$ R2

TGF $\beta 22$ is an important component in TGF- $\beta$ signaling. Its loss or reduced expression may impair TGF- $\beta$ signaling. To examine if miR-93 is involved in the abrogation of this signaling pathway, the phosphorylation of Smad2/3, a key protein in this pathway, was detected in 


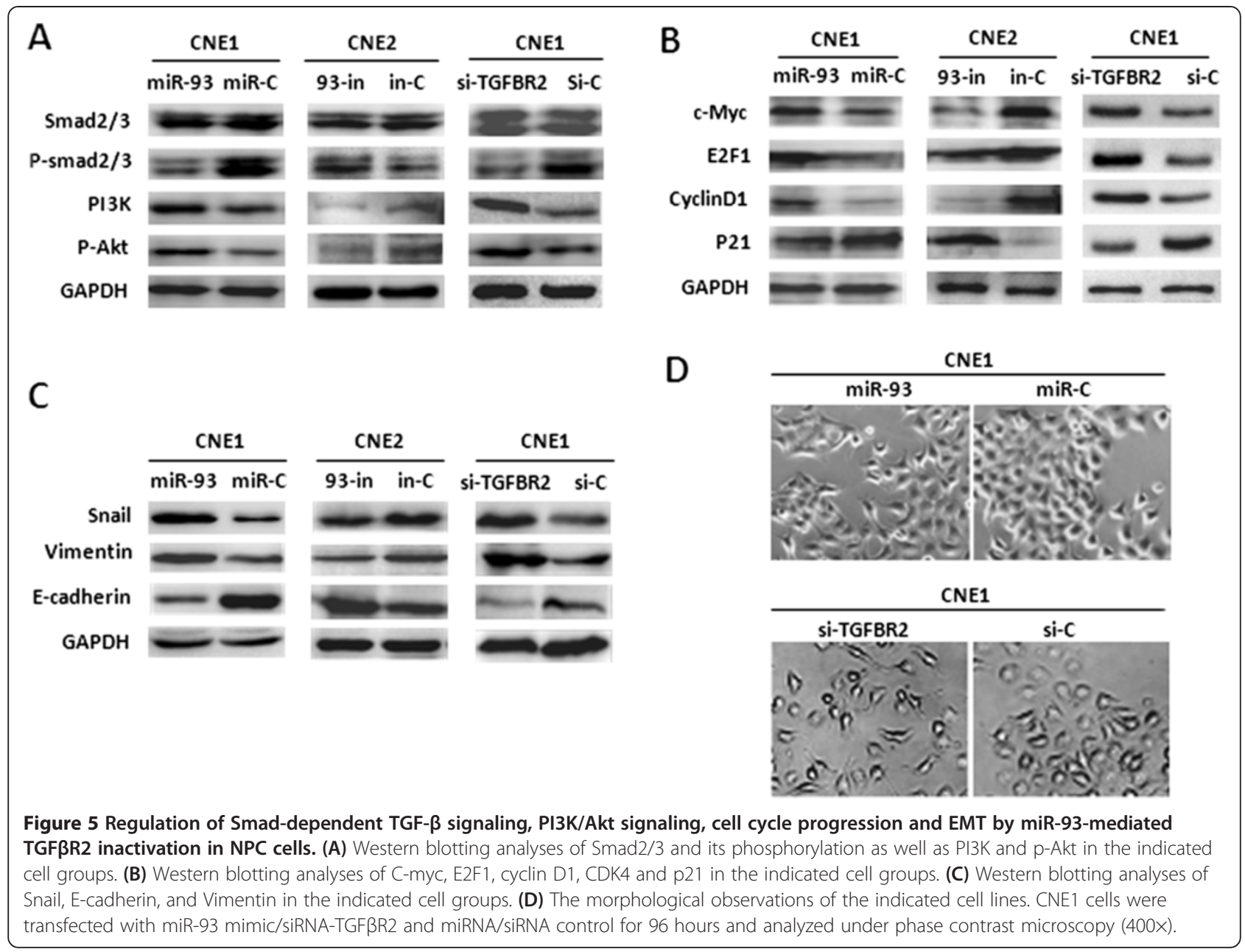

CNE1 cells and CNE2 cells treated with miR-93 mimic and inhibitor respectively. As shown in Figure $5 \mathrm{~A}$ and Additional file 2: Figure S12A, the introduction of miR-93 did attenuate $\mathrm{p}-\mathrm{Smad} 2 / 3$ expression, whereas silencing of miR-93 increased p-Smad2/3 expression. Notably, the reduction of $\mathrm{p}-\mathrm{Smad} 2 / 3$ expression was also observed in CNE1 treated with siRNA-TGF $\beta$ R2, similar to the effect of miR-93 (Figure 5A). These data indicate that miR-93 attenuates Smad-dependent TGF- $\beta$ signal though suppressing TGF $\beta 2$.

PI3K/Akt signaling pathway is a central regulator in cancer cell proliferation, metastasis and EMT process. Multiple studies have suggested the existence of direct [52,53] or indirect [54-57] crosstalk between TGF- $\beta$ signaling and PI3K/Akt signaling, so we wonder whether PI3K/Akt pathway is also involved in NPC aggressiveness in the presence of miR-93-mediated TGF $\beta R 2$ inactivation. To test this, we examined the expressions of PI3K and p-Akt, after treating CNE1 and CNE2 cells with miR-93 mimic or siRNA-TGFßR2 and miR-93 inhibitor respectively. Our results showed that miR-93 mimic could elevate the expressions of PI3K and p-Akt in CNE1 cells, whereas its inhibitor could reduce the expressions of PI3K and p-Akt in CNE2. As expected, siRNA-TGFßR2 displayed a consentaneous phenocopy with the effect of miR-93 mimic in CNE1 cells (Figure 5A, Additional file 2: Figure S12A), suggesting the downregulated TGF $\beta R 2$ could enhance PI3K/Akt pathway.

Next, we performed western blotting to check the expression alterations of some important proteins related to cell proliferation, cell cycle and EMT process in CNE1 cells transfected with miR-93 mimic or siRNA-TGF $\beta$ R2 and in CNE2 cells transfected with miR-93 inhibitor. Notably, miR-93 mimic or siRNA-TGF $\beta 2$ could increase the expression of c-myc, E2F1 and cyclin D1, and reduce p21 expression in CNE1 cells. Conversely, miR-93 inhibitor could reduce the expression of c-myc, E2F1 and cyclin D1, and increase p21 expression in CNE2 cells (Figure 5B, Additional file 2: Figure S12B).

EMT has been regarded as an important mechanism that facilitates cancer cell migration and leads to metastasis, so we also tested whether miR-93 is involved in 
the EMT to influence cancer metastasis. As shown in Figure 5C and Additional file 2: Figure S12C, both miR-93 mimic and siRNA-TGF $\beta 22$ resulted in the highly expressed transcriptional factor Snail, reduced E-cadherin expression and increased Vimentin expression in CNE1 cells, whereas miR-93 inhibitor caused opposite alterations in CNE2 cells. Morphological observation showed that miR-93 mimic or siRNA-treated NPC cells lost their cell-to-cell adhesions and acquired spindle-like morphology, whereas the control cells remained cobblestone-like epithelial appearance (Figure 5D).

Collectively, these data suggest that miR-93-mediated TGF $\beta R 2$ down-regulation could result in the attenuation of Smad-dependent TGF- $\beta$ signaling and the activation of PI3K/Akt pathway in NPC aggressiveness. Some cell cycle, cell proliferation and EMT-associated genes were altered in NPC cells in the presence of miR-93-mediated TGF $\beta 2$ down-regulation.

TGF- $\beta 1$ is one of the most important TGF- $\beta$ signaling components, so we also detected its expression alteration in the presence of miR-93-mediated TGF $\beta 2$ downregulation. Notably, miR-93 or siRNA-TGF $\beta$ R2 could give rise to an increased TGF- $\beta 1$ expression in CNE1 cells and an increased TGF- $\beta 1$ secretion in the culture supernatants of CNE1 cells, whereas miR-93 inhibitor enabled inverse alterations in CNE2 cells (Additional file 2: Figure S9), suggesting a possible feedback loop from miR-93-mediated TGF $\beta R 2$ to TGF- $\beta 1$ existed in NPC cells.

\section{MiR-93 and TGF $\beta$ R2 were clinically associated with NPC aggressiveness}

To further support our finding, we finally investigated the clinical relevance of miR-93 and TGF $\beta R 2$ in an additional set of clinical samples. The correlations of clinical TNM classification with the expression levels of miR-93 and TGF $\beta R 2$ were analyzed (M classification was not analyzed due to few patients with distant metastasis). We observed that the expressions of miR-93 positively correlated with $\mathrm{T} / \mathrm{N}$ classification and clinical stage respectively (Figure 6A) and TGF $\beta$ R2 expression was negatively correlated with $\mathrm{T} / \mathrm{N}$ classification and clinical stage respectively (Figure 6B), supporting that miR-93-mediated TGF $\beta R 2$ down-regulation was closely linked to NPC aggressiveness.

\section{Discussion}

The role of TGFBR2 in oncogenesis has been investigated in several cancer types. Loss of TGF $\beta 22$ was reported in nasopharyngeal carcinoma (NPC) in our previous study [40]. The downregulation of TGFBR2 expression in cancer cells can be caused by multiple mechanisms, including hypermethylation of the TGFBR2 promoter and, as we show here, through miRNA regulation. MiR-17-92 and its paralogues are the best-known miRNA clusters. Their members have pivotal roles in normal development, and dysregulation of their expressions leads to a wide array of diseases and cancers. In the beginning of our study, we
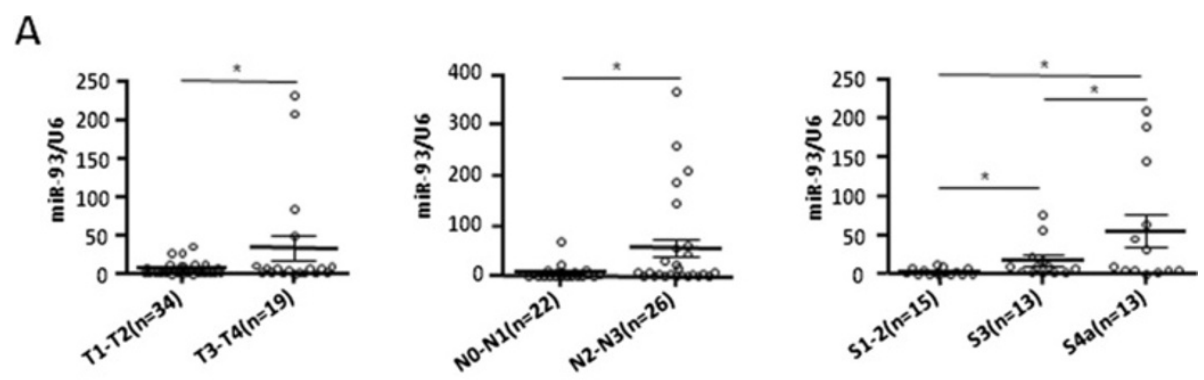

B
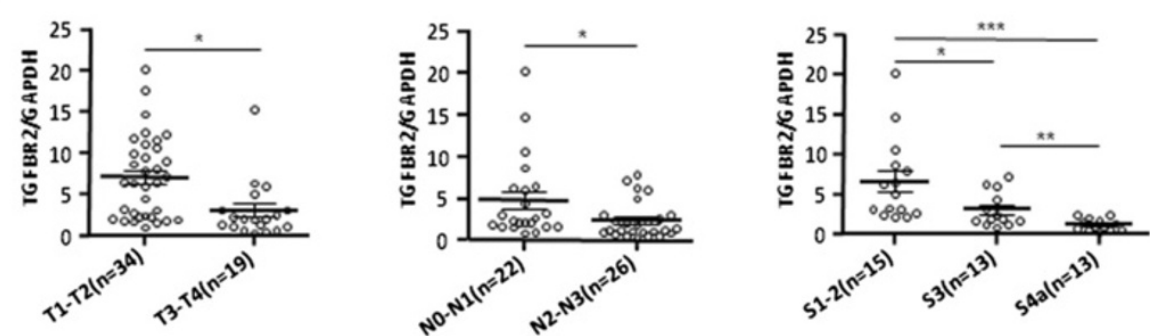

Figure 6 MiR-93 and TGF $\beta$ R2 were clinically associated with NPC aggressiveness. (A) The detection of miR-93 expression by qRT-PCR in an additional set of primary NPC samples. As showed in the plot diagrams, the miR-93 expression was positively correlated with T, N classification and clinical staging. Values represent mean $\pm S D,{ }^{*} p<0.05$ (B) qRT-PCR analysis of TGF $\beta R 2$ mRNA expression showed a negative correlation of TGF $\beta R 2$ expression with T and $N$ classifications and clinical staging in scatter plot diagrams. Values represent mean $\pm S D,{ }^{*} P<0.05$, ${ }^{* *} \mathrm{P}<0.01,{ }^{* * *} \mathrm{P}<0.001$. 
actually failed to find miRNAs targeting TGFBR2 in NPC using a global miRNA expression profiling analysis of clinical samples (data not shown but available in GEO database. Accession Number is GSE42945), similar to other studies [58,59]. Alternatively, based on this miRNA expression profiling data, we next re-classified clinical samples into high and low TGF $\beta 2$ expression NPC subgroups and normal control group, and interestingly discovered a cluster set of TGFßR2-associated miRNAs (miR-93, miR20a, miR-20b and miR-18a), which all belong to miR-1792 cluster and its paralogues.

To our knowledge, few lines of evidence support that miR-17-92 cluster and its paralogues may contribute to the regulation of TGF $\beta R 2$ function in cancer. MiR-17-5p and miR-20a could repress TGFßR2 in HCT116 p53null human colon carcinoma cells [60]. Stefano Volinia et al. also experimentally confirmed that TGFBR2 is a target of miR-20a by luciferase reporter assay [61]. Recently, some studies have identified some miR-93 targets that mediate oncogenesis and cancer progression in several different cancer types [30,32,33,35,62]. Our study finds that TGFBR2 is a major miR-93 target that mediates the oncogenic function in NPC.

In the current study, we conducted an integrated approach comprising in vitro, in vivo and clinical analyses to explore the roles of this miR-93-mediated TGF $\beta$ R2 down-regulation. Multiple sets of clinical data were used to raise our hypotheses and support our research conclusions. Our results demonstrate that miR-93-mediated TGF $\beta R 2$ down-regulation contributes to NPC aggressiveness including cell growth and proliferation as well as cancer metastasis and invasion. A recent prognostic study reported a correlation of miR-93 expression level with NPC prognosis [63]. This study didn't further investigate the associated molecular mechanism, but it supported our findings. Combining this research data with ours, we conclude that up-regulated miR-93 and down-regulated TGF $\beta 22$ may be a dominant functional combination in clinical NPC aggressiveness; miR-93 promotes NPC aggressiveness through down-regulating TGF $\beta R 2$.

It is best known that TGF- $\beta$ and PI3K/AKT signal transductions are two pivotal pathways that control cell function. Importantly, PI3K/Akt pathway could be directly or indirectly regulated by TGF- $\beta[52-57,64]$. In the present study, we provided further evidence that miR93-mediated TGF $\beta$ R2 inactivation not only pulled down the TGF- $\beta$ signaling but also activated PI3K/Akt pathway in NPC aggressiveness. Subsequently, we observed the high expression of two important transcriptional factors, c-myc and snail that are closely associated with cancer cell proliferation, migration and EMT process. The obvious expression alterations of some important genes related to cell proliferation, cell cycle and EMT concurrently appeared in NPC cells in the presence of miR-93-mediated TGF $\beta R 2$ inactivation. In Particular, the knockdown of TGFBR2 by siRNA displays a consentaneous phenocopy with the effect of miR-93. These date support a major involvement of miR-93-medited TGF $\beta$ R2 inactivation that drives down the TGF- $\beta$ signaling and activates PI3K/Akt pathway in NPC aggressiveness.

In addition, a relatively high intracellular expression and secretion of TGF- $\beta 1$ were observed upon miR-93mediated TGF $\beta$ R2 down-regulation, which was consistent with a report by Munoz [65] who believed that it was possibly due to the attenuated TGF- $\beta$ signaling pathway. This hints its undefined effects on NPC aggressiveness, which deserves further investigations.

\section{Conclusions}

Our study identifies a miR-93-mediated TGF $\beta R 2$ downregulation in NPC and its link to NPC aggressiveness. We also discovered an involvement of Smad-dependent TGF- $\beta$ signaling attenuation and PI3K/Akt activation. This study presents some useful insights into molecular mechanisms underlying NPC aggressiveness and provides potential implications for clinical application.

\section{Materials and methods}

\section{Clinical samples and cell lines}

14 fresh NPC specimens and 8 fresh NP were used for miRNA expression profiling analysis, microarray validation, and correlation analysis. A second cohort of NPC containing 55 fresh-frozen NPC specimens with TNM classification was used for clinical evaluations. 300 paraffin embedded sections from NPC, atypical hyperplasia (AH), normal squamous epithelium (NS) and normal nasopharynx epithelium (NN) were employed for histological examinations. All tissue samples were collected from the patients that were confirmed by pathological examination and not pretreated with radiotherapy or chemotherapy in Zhongshan Hospital, Zhongshan City, Guangdong, China. Staging was performed according to the 1992 Fuzhou NPC staging system of China [66]. Clinical tissue studies for research purposes have received patient's informed consents and the approval from the Ethics Committee of Southern Medical University, China. Immortalized primary nasopharyngeal epithelial cell line (NP69) and 4 NPC cell lines (CNE1, CNE2, 5-8 F, 6-10B) were obtained from Cancer research institute of Southern medical university, Guangzhou, China.

\section{MiRNA expression profiling analysis}

The miRNA microarrays (CCDTM-miRNA 850-V4p1.4) were provided by Infectious Disease and Immunogenetics Section, DTM, Clinical Center of the National Institutes of Health, USA. Briefly, 7-10 $\mu$ g of total RNA from each sample was used for hybridization on miRNA microarray 
that was labeled with Exiqon LNA microRNA Array power labeling kit (Exiqon) according to manufacturer's instruction. The microarray was hybridized at $25^{\circ} \mathrm{C}$ for $18 \mathrm{hrs}$, washed in washing buffers at $37^{\circ} \mathrm{C}$ for $1 \mathrm{~min}$, and scanned on a LuxScan $10 \mathrm{k}$ microarray scanner (LuxScanTM10K-A, CapitalBio Corporation). Resulting data were quantified, normalized and analyzed by the LuxScanTM 3.0 software (CapitalBio Corporation, China), and then uploaded to the mAdb database (http://nciarray. nci.nih.gov).

The raw data were filtered according to standard procedure to exclude spots with minimum intensity and size, normalized using Lowess Smoother, and retrieved by the BRBArray-Tool (http://linus.nci.nih.gov/BRB-ArrayTools. $\mathrm{html})$. Clustering and visualization of expression profiles were preformed with Cluster and Treeview [67].

\section{Extraction of total RNA and quantitative RT-PCR}

Total RNAs were extracted from tissues and cell lines with TRIzol (Invitrogen) according to the user manual. For mRNA expression analysis, $1 \mu \mathrm{g}$ of total RNA was used for RT using PrimerScriptTM RT Kit following the manufacturers protocol (TaKaRa), and real-time PCR was performed using SYBR Premix Ex Taq ${ }^{\circ}$ Real Time PCR Kit (TaKaRa) on an Mx3000P Stratagene. All data were normalized to GAPDH expression and further normalized to the negative control unless otherwise indicated. Primer sequences for TGF $\beta 2$ (forward: 5'-AAGATGACCGCTC TGACATCA-3', reverse: 5'-CTTATAGACCTCAGCGA C-3') and GAPDH (forward: 5'-CCATGAGAAGTATGA CAAC AGCC-3', reverse: 5'-GGGTGCTAAGCAG TTG GTG-3') were acquired from Primer-bank (http://pga. mgh.harvard.edu/primerbank/). For miRNA expression analysis, mature miRNAs were reverse-transcribed for subsequent real-time PCR using All-in-One ${ }^{\mathrm{rm}}$ miRNA qRT-PCR Detection Kit following the manufacturer's protocol (GeneCopoeia). All data were normalized to U6 expression. The fold changes were calculated by relative quantification $\left(2^{-\Delta \Delta C t}\right)$. QRT-PCR was conducted for each sample in triplicate.

\section{Cell culture and transfections}

NPC cell lines were cultured in RPMI-1640 (HyClone) with $10 \%$ calf serum (Gibco). For transfection, the medium was changed to the Dulbecco's modified Eagle's medium, DMEM (Gibco) with 10\% fetal bovine serum (Gibco). Cells were maintained in a humidified atmosphere of $5 \% \mathrm{CO}_{2}$ at $37^{\circ} \mathrm{C}$ and seeded on six-well plates (NEST, China) 24 hours prior to transfection. SiRNA-TGF $\beta R 2-$ 1515 (Additional file 1: Table S4, Additional file 2: Figure S10) (GenePharma), miRNA-93 mimic and inhibitor (GenePharma) were transfected into cells respectively at a final concentration of $50 \mathrm{nmol} / \mathrm{L}$ using Lipofectamine ${ }^{\mathrm{max}} 2000$ (Invitrogen) in serum-free conditions. After 5 hours, the medium was changed to fresh DMEM (Gibco) with $10 \%$ fetal bovine serum.

\section{Dual luciferase assay}

To generate the luciferase reporter constructs psiCHECK2TGFßR2-3'UTR(wt) and psiCHECK2-TGFßR2-3'UTR(mut), complimentary oligonucleotides containing the wild type 3'UTR of TGF $\beta R 2$ (3'UTR of TGF $\beta R 2$ was divided into 2 segments (0.15 KB-0.6 KB and 1.5 KB-2.5 KB) and TGFßR2 3'UTR with point mutations in miR-93 target sites, respectively, were annealed. Oligonucleotide sequences were as follows: TGF $\beta R 2$-wt $0.15 \mathrm{~kb}-0.6 \mathrm{~kb}$ : forward5' -ATCGCTCGAGCAGCAGGGAGTGGGTGA CAT-3', reverse: $5^{\prime}$-AT CGCGGCCGCTGGCTGTGAG ACATGGAGCC-3'. 1.5 kb-2.5 kb: forward: 5' -ATCGTC GAGTC AGTGTGGGTGGGCTGAGA-3'; reverse: 5' -A TCGCGGCCGCGGGAACAGGAGGCAGGATG C-3'. TGFßR2-mut: forward: 5'-AACCGAGGTTCCCGCTCC AAGAAGC-3', reverse: 5' -CTCCAATGCAGAGGGTAA AA CTATT-3'. Annealed oligonucleotides were ligated into the Xhol/NotI site of psi-CHECK2 renilla/firefly dual-luciferase expression vector. Mutant reporter plasmids were obtained from this plasmid using a KOD-PlusMutagenesis Kit (SMK-101, Toyobo Co., Ltd. Life Science Department, Osaka Japan). All inserts were verified by DNA sequencing. Luciferase assays were conducted using 293 T cells plated in a 24-well plate (NEST). Transfections were performed using Lipofectamine ${ }^{\mathrm{mm}} 2000$ (Invitrogen) in OptiMEM serum free media (Gibco).

\section{Cell migration and invasion assays}

For migration assays, $2 \times 10^{5} \mathrm{NPC}$ cells transfected with miRNA-93 mimic or siRNA- TGF $\beta 22$ and miRNA-93 inhibitor respectively for 48 hours were re-suspended in serum-free media and placed in inserts containing $8 \mu \mathrm{m}$ pores (Corning) without extracellular matrix coating (BD Biosciences, San Jose, CA, US). DMEM containing 10\% FBS was added to the bottom chamber. After 18 hours and 24 hours of incubation, the cells on the lower surface of the filter were fixed and stained followed by microscopic examination. The number of cells in five random optical fields (100× magnifications) from triplicate filters was averaged. For in vitro invasion assays, the inserts of the chambers to which the cells were seeded were coated with Matrigel (BD Biosciences).

\section{Cell proliferation, colony formation and cell cycle analyses}

Cell proliferation was analyzed using MTT assay (Sigma, St. Louis, USA). Briefly, CNE-1 cells $\left(5 \times 10^{3}\right)$ and CNE- 2 cells $\left(3 \times 10^{3}\right)$ were plated onto 96-well plates (NEST) respectively in $100 \mu \mathrm{L}$ of growth medium and allowed to adhere overnight. The cells were then transfected with $50 \mathrm{~nm}$ of miR-93 mimic or siRNA and inhibitor 
respectively. At different time points ( $24 \mathrm{~h}, 48 \mathrm{~h}$ and $72 \mathrm{~h}$ ), the culture medium was removed and replaced with culture medium containing $10 \mu \mathrm{L}$ of sterile MTT dye $(5 \mathrm{mg} /$ $\mathrm{mL})$. After incubation at $37^{\circ} \mathrm{C}$ for 4 hours, the MTT solution was removed, and $150 \mu \mathrm{L}$ of dimethyl sulfoxide (DMSO) was added to dissolve the formazan crystals. Spectrometric absorbance at $490 \mathrm{~nm}$ was measured by BioTek ELx800 microplate photometer (BioTek ELx800, SN211805, US).

Colony Formation Assays were performed. CNE-1 and CNE2 cells were transfected respectively with miR-93 mimic or SiRNA-TGF $\beta 22$ and miR-93 inhibitor and for $24 \mathrm{~h}$ and were pated in 6-well plates at $2 \times 10^{2}$ for 2 weeks. The plates were then washed twice with PBS, fixed with methanol-acetic acid $(3: 1 \mathrm{~V} / \mathrm{V})$, and stained with $0.5 \%$ cristal violet. The number of colonies was counted under the microscope.

For cell cycle analysis, CNE1 cells transfected with miR-93 mimic or siRNA-TGF $\beta 2$ and CNE2 cells transfected with miR-93 inhibitor were fixed in 70\% ice-cold ethanol for 48 hours at $4^{\circ} \mathrm{C}$, stained by incubation with PBS containing $10 \mu \mathrm{g} / \mathrm{mL}$ propidium iodide and $0.5 \mathrm{mg} / \mathrm{mL}$ RNase A for $15 \mathrm{~min}$ at $37^{\circ} \mathrm{C}$, and analyzed for the DNA content of labeled cells by FACS Caliber Cytometry (BD Bioscience). Each experiment was done in triplicate.

\section{Lentiviral production and transduction}

Lentivirus (GV209, H1-MCS-CMV-EGFP) particles carrying hsa-pri-miR-93 precursor and its control were purchased from GeneChem, Shanghai, China [68] (Additional file 2: Figure S11A, B). The lentiviral transduction of CNE1 cells was carried out according to the manufactures' protocol. The resulting cells were seeded onto 96-well plates and cultured for 3 weeks to produce a stable miR-93-overexpressing CNE1 cells and CNE1 control cells (Additional file 2: Figure S11C). The high expression of miR-93 was validated by quantitative RT-PCR (Additional file 2: Figure S11D).

\section{Tumor xenografts in nude mice}

The experimental protocol was approved by the Animal Care and Use Committee of Southern Medical University. All mice of 4-5 weeks old and 18-20 g in weight were provided by the Central Animal Facility of Southern Medical University.

To evaluate tumor growth in mouse models, $200 \mu \mathrm{L}$ of Cell suspension from $1 \times 10^{7} \mathrm{CNE} 1$ expressing GFP/miR93 and CNE1 cells expressing vector control were subcutaneously injected into the left and right sides of the back of each mouse respectively. The tumor sizes were measured periodically and calculated using the formula = $0.5 \times a \times b^{2}$ ( $a$ and $b$ were the long and short diameters of the tumors respectively). After mice were sacrificed in
3 weeks, tumors were collected from mice for IHC detection of TGF $\beta R 2$ expression.

An imageable technique in mouse models has been developed in our laboratory before [69]. To evaluate tumor metastasis in mouse models, we firstly made a small cut on the abdominal region of each mouse, carefully pushed its liver out of abdominal cavity, injected $50 \mu \mathrm{L}$ of CNE1 cells $\left(5 \times 10^{6}\right)$ expressing GFP/miR-93 or an equal number of control cells under the liver envelope of each mouse ( 8 mice for each group), and then softly pushed its liver back after cleaning and lightly pressing the pinhole with alcohol cotton balls for two minutes. All mice were sacrificed in 3 weeks. Their whole bodies and resected internal organs (on culture plates) were subjected to fluorescent image detection under LT-9MACIMSYSPLUS whole body imaging system (Encinitas, CA, USA).

\section{Immunohistochemical examination}

Paraffin-fixed NPC sections and nude mice tumor sections were immunostained for TGF $3 R 2$ using the UltraSensitive S-P IHC Kit (Maixin-Bio, Fujian, China) and primary antibody against TGF $\beta$ R2 (1:100 dilution, Abcam), and then colorated with DAB Kit (Maixin-Bio, China). The immunohistochemically stained tissue sections were reviewed and scored by two pathologists independently, blinded to the clinical parameters. Staining intensity was scored as previously described [70]. The extent of the staining, defined as the percentage of positive staining areas of tumor cells or normal nasopharyngeal epithelial cells in relation to the whole tissue area, was scored on a scale of 0 to 4 as the following: $0,<10 \% ; 1,10-25 \% ; 2,26-$ $50 \%$; $3,50-75 \%$; and $4,>76 \%$. The sum of the stainingintensity and staining-extent scores was used as the final staining score for TGF $\beta R 2(0-7)$. For statistical analysis, a final staining scores of 0-5 and 6-7 were respectively considered to be low and high TGF $\beta$ R2 expression.

\section{Western blot analysis}

Cell lysate was prepared using RIPA buffer with protease inhibitors and quantified using the BCA protein assay (BioTek, China). Protein $(20 \mu \mathrm{g})$ was loaded onto a $10 \%$ SDS-PAGE gel that was then transferred onto PVDF membrane and incubated with anti-TGF $\beta$ R2 (Bioworld Technology, MN.US), anti-TGF- $\beta 1$ (Cell Signaling Technology), anti-PI3K (Cell Signaling Technology), anti-p-Akt (p-Ser473, Abzoom), anti-c-myc (Santa Cruz), anti-E2F1 (Santa Cruz), anti-CCND1 (Santa Cruz), anti-p21 (Santa Cruz), anti-E-cadherin (Bioworld Technology, MN.US), anti-Vimentin (Bioworld Technology, MN.US), and antiSnail (Bioworld Technology, MN.US) at $4^{\circ} \mathrm{C}$ overnight in blocker (3\% non-fat dry milk/BSA in TTBS) followed by incubation with HRP-conjugated secondary anti mouse (ZSGB-Bio, China). Protein was normalized with GAPDH (Abmart). 


\section{Enzyme-linked immunosorbent assay (ELISA)}

CNE1 cells transfected with miR-93 mimic or siRNATGF $\beta R 2$ and CNE2 cells transfected with miR-93 inhibitor were incubated in $8 \mathrm{ml}$ RPMI-1640 (HyClone) with $10 \%$ calf serum (Gibco) for 48 hours. When cells were harvested, the media were placed in the ELISA plates (KeyGen Biotech Co. Ltd, China). ELISA of TGF- $\beta 1$ was performed following the routine manual.

\section{Statistical analysis}

All statistical analyses were performed by the SPSS 13.0 statistical software package (SPSS Inc. Chicago, IL, USA). The Kruskal Wallis test and $\chi^{2}$ test were used to compare gene expression levels of different histological types. The $X^{2}$ test was used to analyze the relationship between the levels of TGF $\beta$ R2 expression and clinicopathologic characteristics. Survival curves were plotted using the KaplanMeier method and compared using the log-rank test. The significances of various variables in survival were analyzed using the multivariate Cox proportional hazards model. Two-tailed Student's $t$ test was used to determine the difference between two groups, while ANOVA was used for the comparison of more than two groups. Fisher's exact test was employed when sample sizes were relatively small. The differences were considered to be statistically significant when $\mathrm{p}$-value $<0.05$. All data were presented as mean \pm SD or SEM unless otherwise noted.

\section{Additional files}

Additional file 1: Table S1. The Correlation between clinicopathologic features and TGFBR2 protein expression in NPC. Table S2. Summary of univariate and multivariate Cox regression analysis of overall survival duration. Table S3. Differentially expressed miRNAs in three subgroups of tissue samples. Table S4. The information of TGFBR2 interference fragments.

Additional file 2: Figure S1. Kaplan-Meier survival analysis of overall survival correlated to NPC TNM classification. Figure S2. QRT-PCR and Western blot analyses of TGFBR2 expression in NPC cell lines and NPC tissue. Figure S3. TGF $\beta$ R2 expression levels in three NPC subgroups. Figure S4. miR-93 expression in NPC cell lines and immortalized Nasopharyngeal epithelial cell, NP69. Figure S5. TargetScan prediction of miRNAs targeting 3' UTR of TGF $\beta R 2$ gene. Figure S6. Effect of miR-93 mimic, inhibitor and siRNA-TGF $\beta$ R2 on cell proliferation as detected by MTT assay. Figure S7. Flow cytometry analysis by FACS Caliber cytometry. Figure S8. MiR-93-mediated TGF $\beta$ R2 down-regulation promotes NPC cell invasion. Figure S9. miR-93-mediated TGF $\beta$ R2 down-regulation results in a relatively higher level of TGF- $\beta 1$ intracellular expression and secretion. Figure S10. The interference efficiency of TGF $\beta R 2$ interference fragments. Figure S11. Lentiviral vectors (miR-93\GV209 and miR-ctrl\GV209) were constructed for the transfection. Figure S12. The histograms of the quantification for the western bands.

\section{Competing interests}

The authors declare that they have no competing interest.

\section{Authors' contributions}

$X L, J L L, H B C$, and WYF designed the experiment, interpreted the data and prepared the manuscript. XML, HZ and LMC conducted the experiment, collected the data and helped to prepare the manuscript. YFY, LZ, JBL, WSC,
EW, FM.M, interpreted the data. KTY was a key advisor of this project. All authors read and approved the final manuscript.

\section{Acknowledgments}

This work was financially supported by grants from National Natural Science Foundation of China (No. 30973292, No. 30872856, No. 30371535 and No. 81171959) and Natural Science Foundation of Guangdong Province (No. S2011010004157 and No. S2013010016388). In addition, we appreciate Miss. CunCun Yuan, Mr. Yaoyong Lu, and Dr. Ying He to provide helpful technical assistances in the present study.

\section{Author details}

${ }^{1}$ Cancer Research Institute and the Provincial Key Laboratory of Functional Proteomics, Southern Medical University, Guangzhou, China. ${ }^{2}$ School of Chinese Traditional Medicine, Southern Medical University, Guangzhou, China. ${ }^{3}$ Department of Otorhinolaryngology, Nanfang Hospital, Southern Medical University, Guangzhou, China. ${ }^{4}$ Departments of Oncology, Nanfang Hospital, Southern Medical University, Guangzhou, China. ${ }^{5}$ Department of Clinical Oncology, Queen Elizabeth Hospital, Guangzhou, Hong Kong. ${ }^{6}$ Infectious Disease and Immunogenetics Section, Department of Transfusion Medicine, Clinical Center, National Institutes of Health, Bethesda, USA. ${ }^{7}$ School of Biotechnology, Southern Medical University, Guangzhou, China. ${ }^{8}$ Molecular Oncology Laboratories, Department of Oncology, Weatherall Institute of Molecular Medicine, University of Oxford, John Radcliffe Hospital, Oxford, UK.

Received: 26 December 2013 Accepted: 1 March 2014 Published: 8 March 2014

\section{References}

1. Meulmeester E, Ten DP: The dynamic roles of TGF-beta in cancer. J Pathol 2011, 223:205-218.

2. Levy L, Hill CS: Alterations in components of the TGF-beta superfamily signaling pathways in human cancer. Cytokine Growth Factor Rev 2006, 17:41-58.

3. Chowdhury S, Ammanamanchi S, Howell GM: Epigenetic Targeting of Transforming Growth Factor beta Receptor II and Implications for Cancer Therapy. Mol Cell Pharmacol 2009, 1:57-70.

4. Brattain MG, Markowitz SD, Willson JK: The type II transforming growth factor-beta receptor as a tumor-suppressor gene. Curr Opin Oncol 1996, 8:49-53.

5. Mamiya T, Yamazaki K, Masugi Y, Mori T, Effendi K, Du W, Hibi T, Tanabe M, Ueda M, Takayama T, Sakamoto M: Reduced transforming growth factorbeta receptor II expression in hepatocellular carcinoma correlates with intrahepatic metastasis. Lab Invest 2010, 90:1339-1345.

6. Ikushima H, Miyazono K: TGFbeta signalling: a complex web in cancer progression. Nat Rev Cancer 2010, 10:415-424.

7. Paiva CE, Drigo SA, Rosa FE, Moraes NF, Caldeira JR, Soares FA, Domingues MA, Rogatto SR: Absence of transforming growth factor-beta type II receptor is associated with poorer prognosis in HER2-negative breast tumours. Ann Oncol 2010, 21:734-740.

8. Yu Y, Kanwar SS, Patel BB, Oh PS, Nautiyal J, Sarkar FH, Majumdar AP: MicroRNA-21 induces stemness by downregulating transforming growth factor beta receptor 2 (TGFbetaR2) in colon cancer cells. Carcinogenesis 2012, 33:68-76.

9. Leemans CR, Braakhuis BJ, Brakenhoff RH: The molecular biology of head and neck cancer. Nat Rev Cancer 2011, 11:9-22.

10. Mishra S, Deng JJ, Gowda PS, Rao MK, Lin CL, Chen CL, Huang T, Sun LZ: Androgen receptor and microRNA-21 axis downregulates transforming growth factor beta receptor II (TGFBR2) expression in prostate cancer. Oncogene 2013.

11. Ogino S, Kawasaki T, Ogawa A, Kirkner GJ, Loda M, Fuchs CS: TGFBR2 mutation is correlated with CpG island methylator phenotype in microsatellite instability-high colorectal cancer. Hum Pathol 2007, 38:614-620.

12. Eads CA, Lord RV, Wickramasinghe K, Long TI, Kurumboor SK, Bernstein L, Peters JH, DeMeester SR, DeMeester TR, Skinner KA, Laird PW: Epigenetic patterns in the progression of esophageal adenocarcinoma. Cancer Res 2001, 61:3410-3418. 
13. Bebek G, Bennett KL, Funchain P, Campbell R, Seth R, Scharpf J, Burkey B, Eng C: Microbiomic subprofiles and MDR1 promoter methylation in head and neck squamous cell carcinoma. Hum Mol Genet 2012, 21:1557-1565.

14. He L, Thomson JM, Hemann MT, Hernando-Monge E, Mu D, Goodson S, Powers S, Cordon-Cardo C, Lowe SW, Hannon GJ, Hammond SM: A microRNA polycistron as a potential human oncogene. Nature 2005 435:828-833.

15. Dews M, Homayouni A, Yu D, Murphy D, Sevignani C, Wentzel E, Furth EE, Lee WM, Enders GH, Mendell JT, Thomas-Tikhonenko A: Augmentation of tumor angiogenesis by a Myc-activated microRNA cluster. Nat Genet 2006, 38:1060-1065

16. Ng EK, Chong WW, Jin H, Lam EK, Shin WY, Yu J, Poon TC, Ng SS, Sung JJ: Differential expression of microRNAs in plasma of patients with colorectal cancer: a potential marker for colorectal cancer screening. Gut 2009, 58:1375-1381.

17. Tsuchida A, Ohno S, Wu W, Borjigin N, Fujita K, Aoki T, Ueda S, Takanashi M, Kuroda M: miR-92 is a key oncogenic component of the miR-17-92 cluster in colon cancer. Cancer Sci 2011, 102:2264-2271.

18. Farazi TA, Horlings HM, Ten HJ, Mihailovic A, Halfwerk H, Morozov P, Brown M, Hafner M, Reyal F, van Kouwenhove M, Kreike B, Sie D, Hovestadt V, Wessels LF, van de Vijver MJ, Tuschl T: MicroRNA sequence and expression analysis in breast tumors by deep sequencing. Cancer Res 2011, 71:4443-4453.

19. Leivonen SK, Makela R, Ostling P, Kohonen P, Haapa-Paananen S, Kleivi K, Enerly E, Aakula A, Hellstrom K, Sahlberg N, Kristensen VN, Borresen-Dale AL, Saviranta P, Perala M, Kallioniemi O: Protein lysate microarray analysis to identify microRNAs regulating estrogen receptor signaling in breast cancer cell lines. Oncogene 2009, 28:3926-3936.

20. Yu Z, Willmarth NE, Zhou J, Katiyar S, Wang M, Liu Y, McCue PA, Quong AA, Lisanti MP, Pestell RG: microRNA 17/20 inhibits cellular invasion and tumor metastasis in breast cancer by heterotypic signaling. Proc Natl Acad Sci U S A 2010, 107:8231-8236.

21. Smith AL, Iwanaga R, Drasin DJ, Micalizzi DS, Vartuli RL, Tan AC, Ford HL: The miR-106b-25 cluster targets Smad7, activates TGF-beta signaling, and induces EMT and tumor initiating cell characteristics downstream of Six1 in human breast cancer. Oncogene 2012, 31:5162-5171.

22. Szafranska AE, Davison TS, John J, Cannon T, Sipos B, Maghnouj A, Labourier E, Hahn SA: MicroRNA expression alterations are linked to tumorigenesis and non-neoplastic processes in pancreatic ductal adenocarcinoma. Oncogene 2007, 26:4442-4452.

23. Morimura R, Komatsu S, Ichikawa D, Takeshita H, Tsujiura M, Nagata $H$, Konishi H, Shiozaki A, Ikoma H, Okamoto K, Ochiai T, Taniguchi H, Otsuji E: Novel diagnostic value of circulating miR-18a in plasma of patients with pancreatic cancer. Br J Cancer 2011, 105:1733-1740.

24. Fan X, Liu Y, Jiang J, Ma Z, Wu H, Liu T, Liu M, Li X, Tang H: miR-20a promotes proliferation and invasion by targeting APP in human ovarian cancer cells. Acta Biochim Biophys Sin (Shanghai) 2010, 42:318-324.

25. Osada H, Takahashi T: let-7 and miR-17-92: small-sized major players in lung cancer development. Cancer Sci 2011, 102:9-17.

26. Heegaard NH, Schetter AJ, Welsh JA, Yoneda M, Bowman ED, Harris CC: Circulating micro-RNA expression profiles in early stage nonsmall cell lung cancer. Int J Cancer 2012, 130:1378-1386.

27. Connolly E, Melegari M, Landgraf $P$, Tchaikovskaya T, Tennant BC, Slagle BL, Rogler LE, Zavolan M, Tuschl T, Rogler CE: Elevated expression of the miR17-92 polycistron and miR-21 in hepadnavirus-associated hepatocellular carcinoma contributes to the malignant phenotype. Am J Pathol 2008, 173:856-864.

28. Shigoka M, Tsuchida A, Matsudo T, Nagakawa $Y$, Saito H, Suzuki Y, Aoki T, Murakami Y, Toyoda H, Kumada T, Bartenschlager R, Kato N, Ikeda M, Takashina T, Tanaka M, Suzuki R, Oikawa K, Takanashi M, Kuroda M: Deregulation of miR-92a expression is implicated in hepatocellular carcinoma development. Pathol Int 2010, 60:351-357.

29. Li Y, Tan W, Neo TW, Aung MO, Wasser S, Lim SG, Tan TM: Role of the miR-106b-25 microRNA cluster in hepatocellular carcinoma. Cancer Sci 2009, 100:1234-1242.

30. Du L, Schageman JJ, Subauste MC, Saber B, Hammond SM, Prudkin L, Wistuba II, Ji L, Roth JA, Minna JD, Pertsemlidis A: miR-93, miR-98, and miR-197 regulate expression of tumor suppressor gene FUS1. Mol Cancer Res 2009, 7:1234-1243.

31. Pineau P, Volinia S, McJunkin K, Marchio A, Battiston C, Terris B, Mazzaferro V, Lowe SW, Croce CM, Dejean A: miR-221 overexpression contributes to liver tumorigenesis. Proc Natl Acad Sci U S A 2010, 107:264-269.
32. Kim YK, Yu J, Han TS, Park SY, Namkoong B, Kim DH, Hur K, Yoo MW, Lee HJ, Yang HK, Kim VN: Functional links between clustered microRNAs: suppression of cell-cycle inhibitors by microRNA clusters in gastric cancer. Nucleic Acids Res 2009, 37:1672-1681.

33. Fang L, Du WW, Yang W, Rutnam ZJ, Peng C, Li H, O'Malley YQ, Askeland RW, Sugg S, Liu M, Mehta T, Deng Z, Yang BB: MiR-93 enhances angiogenesis and metastasis by targeting LATS2. Cell Cycle 2012, 11:4352-4365.

34. Borchert GM, Holton NW, Larson ED: Repression of human activation induced cytidine deaminase by miR-93 and miR-155. BMC Cancer 2011, 11:347.

35. Fang L, Deng Z, Shatseva T, Yang J, Peng C, Du WW, Yee AJ, Ang LC, He C, Shan SW, Yang BB: MicroRNA miR-93 promotes tumor growth and angiogenesis by targeting integrin-beta8. Oncogene 2011, 30:806-821.

36. Fu X, Tian J, Zhang L, Chen Y, Hao Q: Involvement of microRNA-93, a new regulator of PTEN/Akt signaling pathway, in regulation of chemotherapeutic drug cisplatin chemosensitivity in ovarian cancer cells. FEBS Lett 2012, 586:1279-1286.

37. Long J, Wang Y, Wang W, Chang BH, Danesh FR: Identification of microRNA-93 as a novel regulator of vascular endothelial growth factor in hyperglycemic conditions. J Biol Chem 2010, 285:23457-23465.

38. Yeung ML, Yasunaga J, Bennasser Y, Dusetti N, Harris D, Ahmad N, Matsuoka M, Jeang KT: Roles for microRNAs, miR-93 and miR-130b, and tumor protein 53-induced nuclear protein 1 tumor suppressor in cell growth dysregulation by human T-cell lymphotrophic virus 1. Cancer Res 2008 , 68:8976-8985

39. Du L, Zhao Z, Ma X, Hsiao TH, Chen Y, Young E, Suraokar M, Wistuba I, Minna JD, Pertsemlidis A: miR-93-directed downregulation of DAB2 defines a novel oncogenic pathway in lung cancer. Oncogene 2013.

40. Fang W, Li X, Jiang Q, Liu Z, Yang H, Wang S, Xie S, Liu Q, Liu T, Huang J, Xie W, Li Z, Zhao Y, Wang E, Marincola FM, Yao K: Transcriptional patterns, biomarkers and pathways characterizing nasopharyngeal carcinoma of Southern China. J Transl Med 2008, 6:32.

41. Zhang W, Zeng Z, Fan S, Wang J, Yang J, Zhou Y, Li X, Huang D, Liang F, Wu M, Tang K, Cao L, Li X, Xiong W, Li G: Evaluation of the prognostic value of TGF-beta superfamily type I receptor and TGF-beta type II receptor expression in nasopharyngeal carcinoma using high-throughput tissue microarrays. J Mol Histol 2012, 43:297-306.

42. Lu J, He ML, Wang L, Chen Y, Liu X, Dong Q, Chen YC, Peng Y, Yao KT, Kung HF, Li XP: MiR-26a inhibits cell growth and tumorigenesis of nasopharyngeal carcinoma through repression of EZH2. Cancer Res 2011, 71:225-233.

43. Alajez NM, Shi W, Hui AB, Bruce J, Lenarduzzi M, Ito E, Yue S, O'Sullivan B, Liu FF: Enhancer of Zeste homolog $2(E Z H 2)$ is overexpressed in recurrent nasopharyngeal carcinoma and is regulated by miR-26a, miR-101, and miR-98. Cell Death Dis 2010, 1:e85.

44. Luo Z, Dai Y, Zhang L, Jiang C, Li Z, Yang J, McCarthy JB, She X, Zhang W, Ma J, Xiong W, Wu M, Lu J, Li X, Li X, Xiang J, Li G: miR-18a promotes malignant progression by impairing microRNA biogenesis in nasopharyngeal carcinoma. Carcinogenesis 2013, 34:415-425.

45. Yu X, Zhen $Y$, Yang H, Wang $H$, Zhou $Y$, Wang E, Marincola FM, Mai C, Chen $Y$, Wei H, Song Y, Lyu X, Ye Y, Cai L, Wu Q, Zhao M, Hua S, Fu Q, Zhang Y, Yao K, Liu Z, Li X, Fang W: Loss of connective tissue growth factor as an unfavorable prognosis factor activates miR-18b by PI3K/AKT/C-Jun and C-Myc and promotes cell growth in nasopharyngeal carcinoma. Cell Death Dis 2013, 4:e634.

46. Alajez NM, Lenarduzzi M, Ito E, Hui AB, Shi W, Bruce J, Yue S, Huang SH, Xu W, Waldron J, O'Sullivan B, Liu FF: MiR-218 suppresses nasopharyngeal cancer progression through downregulation of survivin and the SLIT2-ROBO1 pathway. Cancer Res 2011, 71:2381-2391.

47. Deng M, Tang H, Zhou Y, Zhou M, Xiong W, Zheng Y, Ye Q, Zeng X, Liao Q, Guo X, Li X, Ma J, Li G: miR-216b suppresses tumor growth and invasion by targeting KRAS in nasopharyngeal carcinoma. J Cell Sci 2011, 124:2997-3005.

48. Yi C, Wang Q, Wang L, Huang Y, Li L, Liu L, Zhou X, Xie G, Kang T, Wang H, Zeng $M$, Ma J, Zeng Y, Yun JP: MiR-663, a microRNA targeting p21 (WAF1/ CIP1), promotes the proliferation and tumorigenesis of nasopharyngeal carcinoma. Oncogene 2012, 31:4421-4433.

49. Du ZM, Hu LF, Wang HY, Yan LX, Zeng YX, Shao JY, Ernberg l: Upregulation of MiR-155 in nasopharyngeal carcinoma is partly driven by LMP1 and LMP2A and downregulates a negative prognostic marker JMJD1A. PLoS One 2011, 6:e19137.

50. Qu C, Liang Z, Huang J, Zhao R, Su C, Wang S, Wang X, Zhang R, Lee MH, Yang H: MiR-205 determines the radioresistance of human nasopharyngeal carcinoma by directly targeting PTEN. Cell Cycle 2012, 11:785-796.

51. Gourzones C, Jimenez AS, Busson P: Profiling of Epstein-Barr virus-encoded microRNAs in nasopharyngeal carcinoma reveals potential biomarkers and oncomirs. Cancer 2012, 118:4634-4635. 
52. Lamouille S, Derynck R: Cell size and invasion in TGF-beta-induced epithelial to mesenchymal transition is regulated by activation of the mTOR pathway. J Cell Biol 2007, 178:437-451.

53. Yi JY, Shin I, Arteaga CL: Type I transforming growth factor beta receptor binds to and activates phosphatidylinositol 3-kinase. J Biol Chem 2005, 280:10870-10876.

54. Xia H, Ooi LL, Hui KM: MicroRNA-216a/217-induced epithelialmesenchymal transition targets PTEN and SMAD7 to promote drug resistance and recurrence of liver cancer. Hepatology 2013, 58:629-641.

55. Kato M, Putta S, Wang M, Yuan H, Lanting L, Nair I, Gunn A, Nakagawa Y, Shimano H, Todorov I, Rossi JJ, Natarajan R: TGF-beta activates Akt kinase through a microRNA-dependent amplifying circuit targeting PTEN. Nat Cell Biol 2009, 11:881-889.

56. Sorrentino A, Thakur N, Grimsby S, Marcusson A, von Bulow V, Schuster N, Zhang S, Heldin CH, Landstrom M: The type I TGF-beta receptor engages TRAF6 to activate TAK1 in a receptor kinase-independent manner. Nat Cell Biol 2008, 10:1199-1207.

57. Yamashita M, Fatyol K, Jin C, Wang X, Liu Z, Zhang YE: TRAF6 mediates Smadindependent activation of JNK and p38 by TGF-beta. Mol Cell 2008, 31:918-924.

58. Li T, Chen JX, Fu XP, Yang S, Zhang Z, Chen K, Li Y: microRNA expression profiling of nasopharyngeal carcinoma. Oncol Rep 2011, 25:1353-1363.

59. Chen HC, Chen GH, Chen YH, Liao WL, Liu CY, Chang KP, Chang YS, Chen SJ: MicroRNA deregulation and pathway alterations in nasopharyngeal carcinoma. Br J Cancer 2009, 100:1002-1011.

60. Dews M, Fox JL, Hultine S, Sundaram P, Wang W, Liu YY, Furth E, Enders GH, El-Deiry W, Schelter JM, Cleary MA, Thomas-Tikhonenko A: The myc-miR-17 92 axis blunts TGF\{beta\} signaling and production of multiple TGF\{beta\}dependent antiangiogenic factors. Cancer Res 2010, 70:8233-8246.

61. Volinia S, Calin GA, Liu CG, Ambs S, Cimmino A, Petrocca F, Visone R, lorio M, Roldo C, Ferracin M, Prueitt RL, Yanaihara N, Lanza G, Scarpa A, Vecchione A, Negrini M, Harris CC, Croce CM: A microRNA expression signature of human solid tumors defines cancer gene targets. Proc Natl Acad Sci U S A 2006, 103:2257-2261.

62. Kim K, Chadalapaka G, Lee SO, Yamada D, Sastre-Garau X, Defossez PA, Park YY, Lee JS, Safe S: Identification of oncogenic microRNA-17-92/ZBTB4/specificity protein axis in breast cancer. Oncogene 2012, 31:1034-1044.

63. Liu N, Chen NY, Cui RX, Li WF, Li Y, Wei RR, Zhang MY, Sun Y, Huang BJ, Chen M, He QM, Jiang N, Chen L, Cho WC, Yun JP, Zeng J, Liu LZ, Li L, Guo Y, Wang HY, $\mathrm{Ma} \mathrm{J}$ : Prognostic value of a microRNA signature in nasopharyngeal carcinoma: a microRNA expression analysis. Lancet Oncol 2012, 13:633-641.

64. Zhang L, Zhou F, Ten DP: Signaling interplay between transforming growth factor-beta receptor and PI3K/AKT pathways in cancer. Trends Biochem Sci 2013, 38:612-620.

65. Munoz NM, Upton M, Rojas A, Washington MK, Lin L, Chytil A, Sozmen EG, Madison BB, Pozzi A, Moon RT, Moses HL, Grady WM: Transforming growth factor beta receptor type II inactivation induces the malignant transformation of intestinal neoplasms initiated by Apc mutation. Cancer Res 2006, 66:9837-9844.

66. Min H, Hong M, Ma J, Zhang E, Zheng Q, Zhang J, Zhang J, Zhang F, Su Y, Qiu F: A new staging system for nasopharyngeal carcinoma in China. Int J Radiat Oncol Biol Phys 1994, 30:1037-1042.

67. Eisen MB, Spellman PT, Brown PO, Botstein D: Cluster analysis and display of genome-wide expression patterns. Proc Natl Acad Sci U S A 1998, 95:14863-14868.

68. Zhou Y, Su Z, Huang Y, Sun T, Chen S, Wu T, Chen G, Xie X, Li B, Du Z: The Zfx gene is expressed in human gliomas and is important in the proliferation and apoptosis of the human malignant glioma cell line U251. J Exp Clin Cancer Res 2011, 30:114.

69. Liu T, Ding Y, Xie W, Li Z, Bai X, Li X, Fang W, Ren C, Wang S, Hoffman RM, Yao K. An imageable metastatic treatment model of nasopharyngeal carcinoma. Clin Cancer Res 2007, 13:3960-3967.

70. Liu Z, Li X, He X, Jiang Q, Xie S, Yu X, Zhen Y, Xiao G, Yao K, Fang W: Decreased expression of updated NESG1 in nasopharyngeal carcinoma: its potential role and preliminarily functional mechanism. Int J Cancer 2011, 128:2562-2571.

doi:10.1186/1476-4598-13-51

Cite this article as: Lyu et al:: TGF $\beta R 2$ is a major target of miR-93 in

nasopharyngeal carcinoma aggressiveness. Molecular Cancer 2014 13:51.

\section{Submit your next manuscript to BioMed Central and take full advantage of:}

- Convenient online submission

- Thorough peer review

- No space constraints or color figure charges

- Immediate publication on acceptance

- Inclusion in PubMed, CAS, Scopus and Google Scholar

- Research which is freely available for redistribution 